\title{
Switching costs in the European postal service. Are there any solutions?
}

\author{
Carlos Pateiro-Rodríguez, Universidade da Coruña \\ Javier Prado-Domínguez, Universidade da Coruña \\ Jesús M. García-Iglesias, Universidad de Extremadura \\ José M. Barreiro-Viñán, Universidade da Coruña
}

\begin{abstract}
This article examines the costs of switching that may exist in the European postal sector, where it is carried out an ambitious process of opening to competition since 1997. Inadequate regulation of the access to some elements of postal infrastructure or services within the scope of the universal postal service exists. This article proposes adaptations to ensure transparent and non-discriminatory access conditions to elements of postal infrastructure in line with the sectorial directives aimed at strengthening competition in the long term in the postal market. The proposed adaptations focus on services such as postcode systems, address databases, post office boxes, delivery boxes, re-direction and return to sender services. All of them can help reduce the switching cost and thus strengthen competition.
\end{abstract}

\section{Keywords}

Liberalization; universal postal service; switching costs; postal network.

\section{JEL classification}

L87; M31; L32; L51. 


\section{Introduction}

Prior to its liberalization, the European postal sector was characterized by typical monopolistic characteristics: it was a market where a dominant provider (usually publically owned) controlled close to 100 per cent of the market share. In response to this situation, three directives were introduced between 1997 and 2008. The three directives were aimed at promoting the opening of the European postal market.

The three postal Directives maintain the universal postal service (UPS), from which the universal service obligations (USOs) are derived, beyond the full market opening (FMO). Keeping the USOs may well put the universal service provider (USP) economic equilibrium in danger, and hence, the Directives design mechanisms in order to finance the additional costs of such USOs: (i) a mechanism to compensate the undertaking concerned from public funds or (ii) a mechanism for the sharing of the net costs of the universal service obligations between providers of services and/or users. The UPS extends to a set of high-quality postal services with which all users are permanently provided at an affordable price throughout the territory. The USP must assume the USOs. These can work as a retention mechanism on the part of providers, and can strengthen switching costs because many of the customers wishing to switch providers need to return to their incumbent provider for some aspect of their mail services. This is due to the potentially incomplete territorial network coverage of an entrant who has not offered UPS or due to inefficiencies in the access regulations of the postal network.

Eighteen years after the first directive, the opening of the postal market in the main EU states has not reached the levels expected in the ambitious liberalization process. The USPs that existed before the liberalization process had still retained a high market share, approximately 90 per cent, in terms of main postal products. Furthermore, as pointed out by Jonsson and Selander (2006) and Pateiro et al (2013a; 2013b), some entry attempts have only reached very low market shares or even failed. Though the markets will be open to competition, the lack of legal restrictions to competition does not mean that competition will be present (Okholm et al 2010: 80). For example, although the markets of Estonia, Finland, Germany, Spain, Sweden, and the United Kingdom (UK) are fully liberalized legally, the actual competition level in these countries is low or has been undisclosed. The dominant provider continues to hold dominance in correspondence and direct mail segment (more than 90 per cent) in most of the European markets: Germany, Hungary, Iceland, Luxembourg, Netherlands, Spain, Portugal, Slovenia, and Slovakia. The most competitive markets are unaddressed delivery and parcel (about 50 per cent). Historically, these are the markets where competition has been allowed for the longest period of time.

Are there any exceptions? A parliamentary decision of 1992 ended with the letter mail monopoly of the incumbent operator Swedish Post (Posten AB). According to Jonsson and Selander (2006: 364), the entry of CityMail, in 1991, was an important trigger for the liberalization. City Mail's bumpy road towards being established as the world's first entrant with a significant portion of a domestic letter mail market has included two bankruptcies and several changes in ownership. According to the findings of Cohen et al (2004), CityMail would not have been able to attract investors if its original business plan had been analyzed correctly.

The reasons for this outcome may stem from the impact of new communication technologies on traditional postal communication (Fève et al 2010) and the current economic crisis (Martin et al 2012; Trinkner and Grossmann 2006). In this context, a declining traditional postal market will not attract a large number of new entrants. In view of the introduction of substitute electronic communication and the opening of the market, the Council of the European Union recommended diversifying the activities of UPS providers by providing electronic business services or other information services. Many European UPS providers, undisputed leaders in the 
declining traditional post, have directed their strategies toward the parcel sector and e-commerce, where its market share was relatively low. Such providers are moving towards a wider range of not strictly postal products to make ensure the profitability of postal network and their human and technical resources.

In addition to the above factors, particularly the impact of new communication technologies on traditional postal communication and the current economic crisis, which have made entering the postal sector less attractive, the authors can also include provider switching costs as an entry barrier. It is difficult for customers to switch providers due to increasing switching costs and a lack of information on existing alternatives (Patterson and Smith 2003; Sharma and Patterson 2000; White and Yanamandram 2007). Furthermore, an established relationship, which is inherent in a historically monopolized postal model, may generate shared values, a stronger identification between the parties, and added profits. These factors act as an entry barrier to competitors (Reinartz and Kumar 2003; Deligonul et al 2006). Finally, the benefit of UPS demands conditions of permanence, ubiquity and frequency, which accentuate the consumer attraction, as opposed to the potential weakness of an entrant who offers incomplete services in the market. This particular characteristic of the regulated postal market, with universal service obligations, encourages customers to stay with their present provider.

There is a set of elements of the postal network and some services to which access can present limitations. Among others, the post office boxes, delivery boxes, postcode system, address database, information on change of address, redirection service and return to sender service. The Member States shall ensure that transparent, non-discriminatory access conditions are available. Access to these elements of the postal infrastructure or services represents real switching costs. The fourth section addresses each and solutions to reduce costs are proposed.

After this introduction, the paper is structured as follows: the second section present a summary of the general regulatory framework for the postal sector in the European Union since 1997. The third section addresses the issue of the switching costs due to its potential impact on competition in the postal sector. In the fourth section, the authors analyze access to specific postal network elements, such as access to PO (post office) boxes, access to postcodes, redirection of mail service, change of address, return to sender service, and access to letterboxes. For each of them the authors propose answers that can help mitigate the switching costs. In the fifth and sixth sections, in this order, the costs of information and search for available choices and termination of a long-term relationship with the incumbent are discussed. Finally conclusions and references are presented.

\section{Liberalization regulatory framework in the European postal sector}

Three postal directives regulate the process of liberalization of the European postal market, as follows:

The first postal Directive is $97 / 67 \mathrm{EC}$ stated that measures to ensure the gradual and controlled liberalization of the market and to secure a proper balance in doing so were necessary to guarantee the obligations and rights of universal service providers (USP), and the free provision of services in the postal sector. The universal service obligations consist of the permanent provision of a service of specified quality at all points in the national territory at affordable prices for all users. Quality, ubiquity, permanence and affordability are the characteristics of UPS7. To the extent necessary to ensure the maintenance of UPS, the Directive

\footnotetext{
${ }^{7}$ For other features of the US see D 97/67, articles 5-6.
} 
(see article 7) creates an area reserved to universal service provider on a part of the postal activity that includes a high proportion of letters. The parameters in terms of weight and price were successively reduced until they disappeared in 2011.

The second is the 2002/39 EC Directive. According to this directive, Member States may continue to reserve services to a universal service provider. At the same time it proposes, if appropriate, the date of 2009 for the full accomplishment of the postal internal market.

The third is the 2008/6 EC Directive. This directive then stated that an FMO would occur by 2009 (this actually occurred in 2011). It also removed the market share (the reserved area) that Directive 97/67 EC had exclusively ascribed to USP8 and stated that the progressive and gradual opening of postal markets to competition had provided USP with sufficient time to implement the necessary modernization and restructuring measures required to ensure their long-term viability under new market conditions. The directive also required Member States to adapt their regulatory systems to a more open environment, in order to improve social welfare (Crew and Kleindorfer 2006).

Each Member State has adapted its internal regulations based on laws of their parliaments and provisions of the respective governments. In turn, the universal service providers adapted their organizational structures and operational frameworks.

\section{Provider switching costs}

Customer dissatisfaction diminishes a postal service provider's customer base, forces the operator to rely on a more volatile customer mix, and erodes the firm's reputation (Levesque and McDougall 1996). This is particularly true in network industries, as the postal service. While some customers take no action at all when dissatisfied, others may take action such complaining directly to the provider about the service or switch suppliers.

Customers can feel compelled to continue their relationship with a service provider due to the user's perceptions of high switching costs (Porter 1980) even if the relationship is not a satisfactory one. The may incur three types of costs if they switch: i) financial costs derived from the switching process; ii) information and search costs on available alternatives, and iii) the termination cost of ending a long relationship with a regular provider.

Switching costs are defined as the customer's perceptions of the additional costs of terminating the present relationship and finding another provider (Patterson and Smith 2003: 108). Switching costs constitute any factor that makes it difficult to or increases the price of a customer switching providers (Valenzuela et al 2005: 243). When the customer leaves their usual provider, they incur two types of loss: i) the loss of the advantages the company had created with its marketing strategy of relationships producing social and economic benefits and empathy, and customization costs and ii) the assumption of direct financial, time and effort costs. These are the two types of positive and negative barriers to switching as stated in the literature on switching costs (Jones et al 2007; Valenzuela et al 2005). Table 1 summarizes the switching cost classifications of Burnham et al (2003) and Jones et al (2002). The authors have adapted this table assuming that the customer may change the postal service provider.

\footnotetext{
${ }^{8}$ An operator such as this will be a designated USP or an incumbent; this term has become widespread in regulatory literature.
} 
Table 1. Classification of switching costs

\begin{tabular}{|c|c|}
\hline $\begin{array}{l}\text { Burnham, Frel, Mahajan } \\
(2003)\end{array}$ & Examples \\
\hline Financial costs & $\begin{array}{l}\text { Loss of volume or length of relationship discounts }(+)^{\mathrm{a}} \text {, payments for breaking } \\
\text { the contract with the present operator }(-)^{\mathrm{b}} \text {, cost of new contracts and guarantees } \\
(-) \text {, mail redirection costs }(-) \text {, return to sender costs }(-) \text {. }\end{array}$ \\
\hline Process costs & $\begin{array}{l}\text { Time cost to find a new postal operator (-), and learning effort to adapt to a new } \\
\text { system of identification, containerization, deposit, collection and invoicing of the } \\
\text { postal deliveries (-). Costs to learn new routines reconfigure hardware and } \\
\text { software to be compatible (-). }\end{array}$ \\
\hline Relationship costs & $\begin{array}{l}\text { Breakdown of the affective bonds created between the customer management and } \\
\text { employees and the postal operator employees or loss of the brand relationship } \\
(+) \text {. Loss of the positive effects on our brand generated by a job well done by the } \\
\text { incumbent }(+) \text {. Costs to reestablish communication networks with other users }(-)\end{array}$ \\
\hline $\begin{array}{l}\text { Jones, Mothersbaugh, Beatty } \\
\text { (2002) }\end{array}$ & Examples \\
\hline Continuity Costs & $\begin{array}{l}\text { Loss of the profits guaranteed by the length of the relationship with the present } \\
\text { postal provider: discounts in volume and/or the composition of deliveries } \\
\text { destination }(+) \text {, permanence }(+) \text {, perception of a probable worsening of the postal } \\
\text { service provided by the entrant operator (-), perception of the damage which a } \\
\text { deficient postal service can cause to our postal communications with our own } \\
\text { customers (-). Risk of loss of customers, both current and potential }(-) \text {. }\end{array}$ \\
\hline Learning costs & $\begin{array}{l}\text { Loss of searching time of other attractive operators (-), adaptation costs to new } \\
\text { preparing, packing and deposit systems of postal deliveries (-), adaptation costs } \\
\text { to new computing supports for the identification of the postal deliveries and } \\
\text { management costs of the new operator virtual office (-). Adaptation costs to the } \\
\text { opening hours (-). Adaptation costs in our resources to transport logistics of the } \\
\text { new postal operator (-). }\end{array}$ \\
\hline Sunk costs & $\begin{array}{l}\text { Previous costs generated to establish the relationship with our present provider: } \\
\text { acquisition of containerization, load and unload and delivery storage elements, } \\
\text { computer programs for invoicing, documents adapted to the operator } \\
\text { methodology }(+) \text {. Adaptation costs in transport elements }(-) \text {. Adaptation costs to } \\
\text { loading and unloading systems of the new operator }(-) \text {. Other costs }(-) \text {. }\end{array}$ \\
\hline & ive barrier to switching; (-) negative barrier to switching. \\
\hline
\end{tabular}

Part of the economic literature assumes that switching costs are anti-competitive. Klemplerer (1995) argues that switching costs generally raise prices and create deadweight losses of the usual kind in a closed oligopoly and may also discourage new entry and so further reduce the market's competitiveness. Because switching costs tend to reduce competition, firms may dissipate more social surplus in costly activities to create them. In the same vein, Armstrong and Sappington (2006: 350) state that reduce customer switching and search costs is the purpose of a policy of liberalization that "can stimulate vibrant, enduring competition that may ultimately substitute for regulatory oversight"9 Insofar as consumers are able to identify and secure postal service provision by another provider, the USP or incumbent will be compelled to offer the lowest price and/or the highest quality, and competition will be reinforced.

However, the presumption that switching costs are anti-competitive is misplaced as a general statement. Fabra and García (2015), in an analysis based upon a continuous-time dynamic equilibrium model in which switching costs are independent and identically distributed across consumers and over time, find that when firms cannot price-discriminate between old and new consumers, the effects of switching costs on prices critically depends on the degree of market share asymmetries. In the case that the market shares become sufficiently symmetric, price competition turns fiercer, and in the long-run, switching cost have a procompetitive effect. However, this result can hardly be in the postal sector, where

\footnotetext{
${ }^{9}$ See Prado and Pateiro (2010) for the application of policies to the postal sector as recommended by Armstrong and Sappington (2006).
} 
the USP that existed before the liberalization process have still retained a high market share, as indicated above.

In response to the entry of competitors in this sector, the USP can adopt different strategies: (i) the incumbent tries to defend its absolute market power by creative renegotiation of terms of agreements with its customers or by offering price cuts in the competitive segment of the market,10 (ii) the incumbent intends to finance price cuts in the competitive area by increasing prices in the non-competitive area;11 (iii) advantages bound to exclusive provider contracts; (iv) a pricing policy in profitable areas to better combat cream skimming practices.12 The costs derived from such maintenance strategies can be considered as customer retention costs. Thus, the USP will support retention costs in the same way that the customer or entrant support the switching costs. In the third section the authors analyze typical provider switching costs.

A clear example of a provider switching cost in telephone service is the cost of not being able to transfer one's current telephone number where portability 13 is not guaranteed. 'Absent such number portability, a consumer might be reluctant to switch suppliers because the switch would require the consumer to inform all friends and associates of her new number or reprint business cards, for example' (Armstrong and Sappington 2006: 351). Shi et al, (2006) studied the effects of number portability in the cellular phone industry. Viard (2007) studied the effect of portability on competition in the phone market.

Similarly, in the postal service, switching costs could be charged if each new entrant adopted a different postcode system, or if the incumbent and the competitor did not have some form of cooperation (a reciprocal access) for the delivery of mail to recipients that have signed a PO box with any of the operators or for delivery in the same home delivery boxes.

In the postal service there is a series of matters which would probably cause important switching costs, both in terms of financial resources and time spent. In addition to access to postcode databases or access to PO boxes, there are other issues that can generate switching such as information on change of address, redirection of mail service, return to sender service or access to letterboxes.

\section{Network and databases access}

This section analyzes access to some elements of the postal network, as follows: access to PO boxes, access to postcodes, redirection of mail service, change of address, return to sender service, and access to letterboxes.

\section{Access to PO boxes}

Delivery to PO boxes is an alternative to home delivery. Clients choose this delivery either because they want to have their mail delivered in the morning earlier than at the regular postman's visit, or because they do not want it delivered at home for whatever reason. The rental of the box is charged to the client-recipient.

\footnotetext{
${ }^{10}$ The Sweden USP Posten AB and other European USPs followed this strategy at the beginning of the 1990s. Many of these contracts were annulled or modified by competition courts.

${ }^{11}$ This strategy can lead a dynamic process of graveyard spiral. See Crew \& Kleindorfer (2005), Prado \& Pateiro (2012)

${ }^{12}$ Cream skimming practices in the postal sector are common in profitable urban areas.

${ }^{13}$ Portability is the guarantee that the customer will keep the same telephone number when they switch service provider.
} 
The address on the envelope specifies the name of the addressee and the number of the box, as well as the postcode to identify the delivery unit of destination.

If the consignor changes the provider, the new operator needs to enter the incumbent's premises in order to leave the deliveries into the box appointed for the addressee. The competitor cannot inject its mail anywhere in the entrance of the delivery unit: this would imply problems with regard to contracting and transferring responsibility.

Access for all competitors and the incumbent to the physical space of the PO boxes is a complex issue. In France, political advisors expressed the idea about building a private corridor behind the PO boxes locked with a key, which would be made available to all licensees as well as to the incumbent. This proposal was abandoned because of the great technical difficulty and prohibitive costs. Therefore, the most practical solution is handing over the mail to the incumbent for loading the PO boxes. Figure 1 represents the case in which an entrant injects the postal items in the incumbent distribution center for delivery to PO Boxes. In this case the entrant does not install PO boxes in their locale.

Figure 1. Entrant access to P.O box of the incumbent

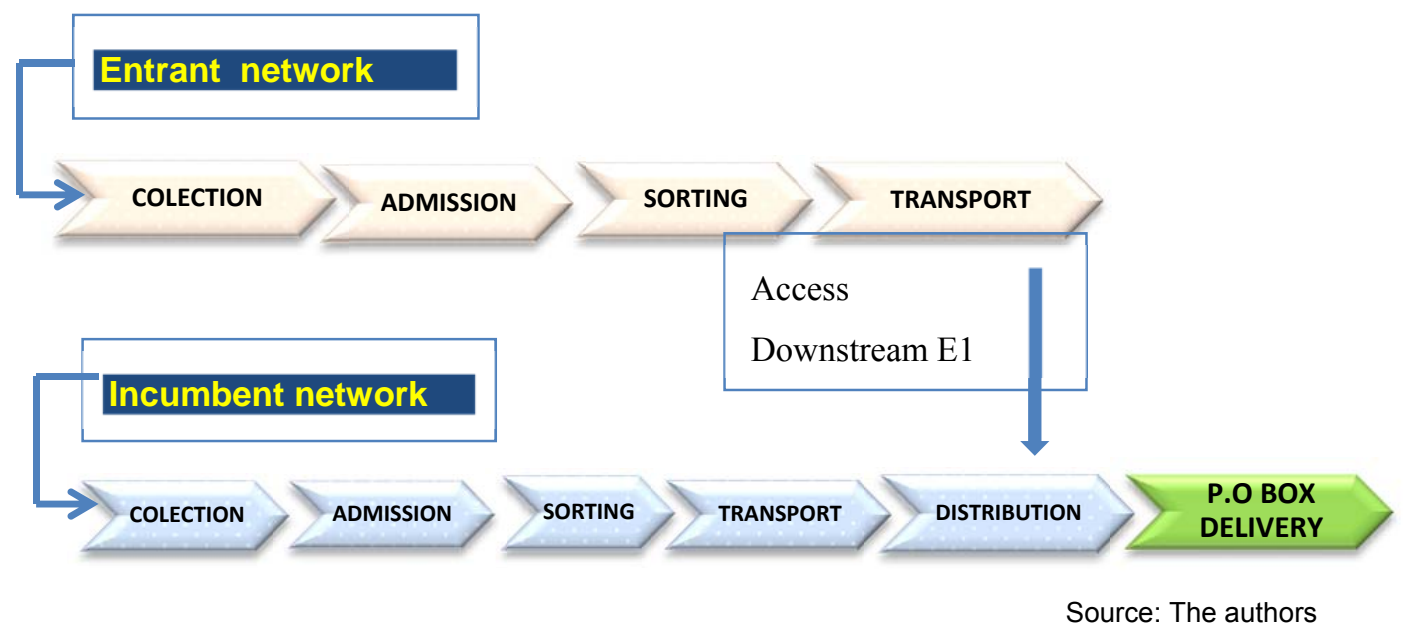

Competitors can place PO boxes in their offices in the same way as the incumbent, but there is no sense in addressees signing the PO Box service with each competitor.

\section{Access to postcodes}

Access to postcodes is not identified by most national regulatory authorities (NRAs) as a bottleneck issue calling for regulatory intervention. Thanks to new technological means, the use of GPS coordinates coding each address is probably a smarter way to proceed (Fratini et al 2010).

However, the basic discount appears when the clients agree to have to present their mail sorted by postcode (work-sharing discounts in the upstream access), allowing the incumbent to avoid sorting. If the client changes the service provider, he could obtain a similar work-sharing discount. But if the incumbent changes the postcode system, the client incurs switching cots because the adaptation of his sorting system by postcode is necessary.

To defend the interests of customers and to strengthen long-term competition, the mandatory access to postcodes could be imposed in order to allow competitors to rightly deliver. It is a question of avoiding the postcode operator in each Member State can freely modify the postcode system.

In Sweden, postcode changes are handled by a Postcode Council with representatives of Posten $A B$, City Mail, the confederation of private postal 
operators and government agencies. The Regulator can put system changes on hold. In the UK, Royal Mail is committed to a policy of no change wherever possible. Postcode changes are only made if it results in a major benefit to the service they provide and new postcodes work in tandem with the old ones for an overlapping 12-month period. In 2015 the Partnership on Transport and Logistics Companies working in Spain submitted a report to the Ministry for Public Works in order to modify the Spanish postcode (from 5 digits to 8 digits). The companies argue the economic and environmental profits stemming from the new postcode. The switching costs in the postcode to users and operators must be weighed up against the expected profits. In any case, it is necessary that the postcode be unique. In that respect, the change of the code would be neutral in terms of switching costs.

\section{Redirection of mail}

The information on redirection service is undoubtedly an important issue that can cause high switching costs if there is not a perfect coordination among operators. Traditionally letters, postcards, direct mail were redirected at the request of the addressee, without costs. This situation has changed in many states where postal operators have established redirection services that allow redirecting postal items to any new national or international address. So, in Spain, France and the UK, the forwarding is done at the request of the addressee for the time period stipulated after having paid the agreed price.14 If a competitor has no access to information about customers of the incumbent redirections, the switching costs are evident: the addressees would have to enter into a redirection contract with each operator. And the senders of the forwardings would lose some communications, which would have a negative effect on their business. Just like in the case of the return to sender service, an additional problem arises when an entrant covering part of the territory may need to deliver mail outside its area (see Figure 3 ).

Figure 2 represents an ideal redirection service. Consider a postal item from $A$ to $B$, addressee Mr. X. The sender entrusts the postal item to any of the operators: incumbent, entrant 1 or entrant 2 . If Mr. X moves to the city $\mathrm{C}$, with which of these operators would $\mathrm{Mr}$. $\mathrm{X}$ hire the redirection service? It no longer really makes sense that a client temporarily changing his address should be obliged to give the information to all licensees. The addressee (in our case Mr. X) hires the redirection service with the Redirection Service Center (RSC) shared by all operators, and he pays a fee for administrative costs. The RSC transmits this information to all providers in real time. The financial costs and time costs are lower for the user. In summary, if there is an RSC, the switching costs are reduced when a customer changes the supplier and thus competition is promoted.

\footnotetext{
${ }^{14}$ Spain: contracts: 1,2 or 6 months: national: $€ 33.28, € 49.90, € 66.09$. International: $€ 50.19, € 75.65$, $€ 99.86$. France: contracts 6 or 12 months: national $€ 24.50$, $€ 44$. International: $€ 69$, $€ 124$. UK: 3,6 , or 12 months from $£ 24.99$ for each last name (in all cases prices in 2015).
} 
Figure 2. Centralized redirection service

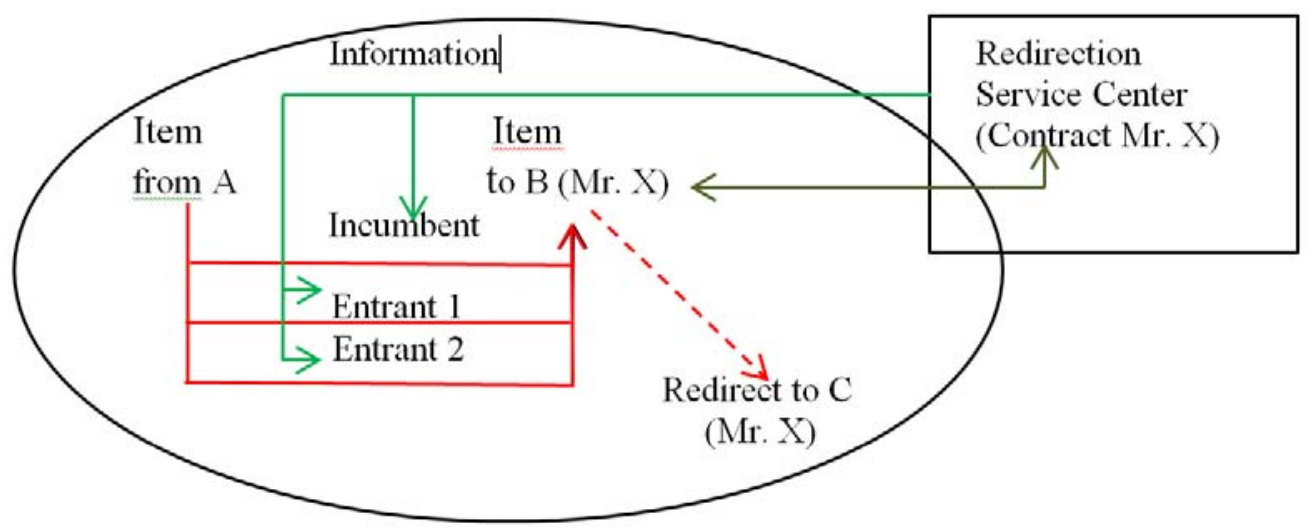

Source: The authors. Green=information redirection; red=postal delivery route; dashed line=redirection route.

\section{Change of address}

Access to the change of address is a more important issue than access to the postcode database for delivering mail (Fratini et al 2010). When someone changes his address, the information is given to the incumbent, which has the most reliable database, when compared with banks, telecom operators or energy providers.

In France, the information is centralized in a database that traces the old and the new addresses. If the new provider has not immediate access to the change of address database, the client will incur switching costs since he needs to communicate his change of address to each operator. As in the case of redirection service, it does not really make sense that a client should be obliged to hire the change of address service to give this information to all competitors. That is why sharing information on address changes could be required by law. In France, new entrants have a CNIL15 authorization, on the same terms as La Poste, to maintain a file containing both the old and new addresses. The following step is about stating the mandatory access to the change of address database.

\section{Return to sender service}

Consider a postal mailing deposited in $A$ and destined to $B$, both within the territory of the entrant (Figure 3). The sender printed the address $C$ on the envelope for return. The incumbent obligation to provide access to a return to sender service reflects the idea that an entrant covering part of the territory may need to deliver mail outside its area depending on where the sender is located ( $C$ in our case). Thus the entrant would need to use the incumbent's network to return undeliverable mail.

The Directive 2008/6 CE says that where several universal service providers with regional postal networks exist, Member States should also assess and, where necessary, ensure their interoperability in order to prevent impediments to the prompt transport of postal items. As the legal and market situation of these elements or services is different among the Member States it is appropriate to only require Member States to adopt an informed decision on the need, extent and choice of the regulatory instrument, including where appropriate on cost sharing.

\footnotetext{
${ }^{15}$ The Commission Nationale de l'Information et des Libertés protects citizens' personal information to prevent any general cross-filing of the population.
} 
This provision is without prejudice to the right of Member States to adopt measures to ensure access to the postal network under conditions of transparency and nondiscrimination.

Figure 3. Return service outside area of the entrant

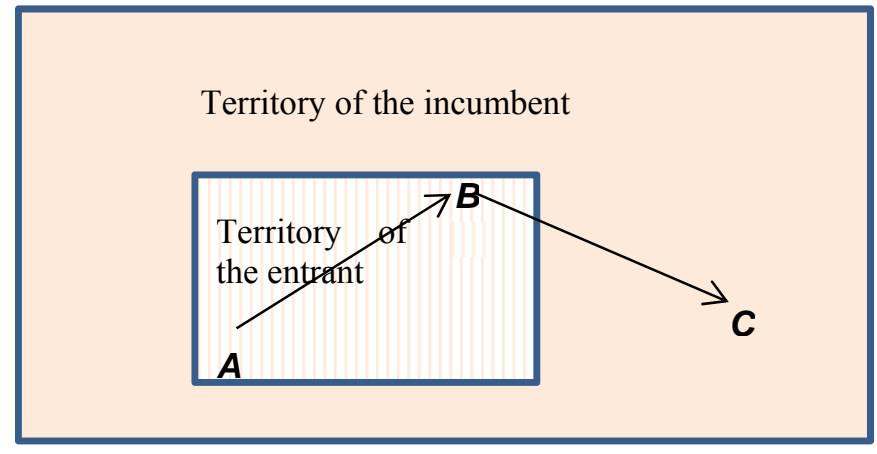

Source: The authors

Cases like those in Figure 3 are not very frequent, but a decision must be adopted. According to ECORYS (2008) the main challenges for the NRAs include arranging interoperability in a multi-operator market.

In France, UK, Spain, and Italy different procedures are in place. The more elegant solution has been adopted in Sweden: the total cost of the return to sender service has been estimated and shared by all operators. Thus, the interoperability of networks is secured for this service.

We propose a solution in this area, in line with that adopted in Sweden. The NRA estimates the cost of return to sender service of postal items that are to be returned to locations outside the territory of the first operator, when he is working in a limited geographical area. This cost will be shared by each of the postal operators in proportion to their volume of mail. This solution reduces the three common types of switching costs: procedural, financial and relational.

\section{Access to letterboxes}

The matter about the access to letterboxes depends on issues such as its owners, location and access to them from the outside of the buildings. In the most of countries such as Spain, France, Portugal, UK, etc., the residents are owners of the letterboxes. As regards its access, there is no problem when it is outside (this happens in Portugal and single-family homes in many countries). A problem arises when the access is from the inside of the buildings or when the incumbent is their owner because it is necessary to authorize the access to the property. In some countries, the access is restricted to the incumbent by law (United States of America, or Austria). In France, Poland, Hungary, Slovakia, Germany, inter alia, the access to the private mailbox has been subject to discussion, regulation and litigation. In most cases, the keys or codes of the entrance slots held by the incumbent are not shared with competitive operators for reasons of safety, privacy, exclusive property and liability.

There have been many discussions regarding the ownership of the letterboxes. It can be argued that these infrastructure elements are not essential facilities or actual bottlenecks in the sense of stable entry barriers, but there may be common ground to assert that the competitive development of the market may be hindered if access to the mentioned elements is refused, according to Plaut Economics (2007: 16).

To avoid switching costs such as those described above and to promote competition in the postal sector, Directive 2008/6/EC states that whenever necessary to protect the interest of users and/or to promote effective competition, 
and in the light of national conditions and national legislation, Member States shall ensure that transparent, non-discriminatory access conditions are available to elements of postal infrastructure or services provided within the scope of the UPS, such as delivery boxes, among others

ECORYS (2008) states that access to the postal infrastructure consists of access to, among others, the letterboxes of individual consumers and businesses, PO boxes, address databases and postal codes.

Here we have another reason why sharing information for letter boxes access could be required by law, provided that security rules are complied with. This is our proposal for access to letterboxes.

\section{Information costs and the search for available choices}

Varela et al (2009) found that a lack of attractive choices in the market or perceiving the present provider as more attractive than others can reduce the likelihood of customer abandonment. When a customer is exposed to negative experiences with his regular provider, he leaves his provider and seeks a more suitable alternative (Sharma and Patterson 2000). However, if alternatives do not exist or are not well known, the customer maintains the relationship with the provider even though it is unsatisfactory. The search costs and the quality information provided by the firms is analyzed by Ghosh and Galbreth (2013). Competition can compel providers to deliver high-quality products to consumers at low prices if consumers can easily identify and secure service from the firms that offer the best products at the lowest prices (Armstrong and Sappington 2006: 350).

In this sense, liberalization policies and national regulatory authorities (NRAs) will have to ensure truthful, transparent and objective low-cost information so that consumers are aware of the available alternatives and, where possible, can switch providers. Measures recommended on this point include i) fast access to information on the existence of competitors, including accessibility, schedules, prices and other supply conditions; ii) cost reductions for the consumer when he switches provider (i.e., to retain the same PO box number and postal code); and iii) a reduction in asymmetric costs that the consumer incurs when he chooses different providers.

Directive 2008/6/EC highlights the importance of information about universal postal services as well as about the characteristics of specific services and their access. Article 6 states that Member States will adopt the necessary measures to ensure that users and postal service providers regularly receive up-to-date information and with sufficient accuracy from UPS providers regarding their universal services. Furthermore, special reference must be made to the access conditions regarding these services as well as to prices and quality levels. The information must be published in an appropriate manner.

In the process of provider switching, the postal user makes a comparative analysis about the quality provided by the new supplier against the previous one. Taking into account this matter, Directive 97/67 CE states that the quality of service expected by users constitutes an essential aspect of the services provided; the evaluation standards for this quality of service and the levels of quality achieved must be published in the interest of users.

Although the legislation enforces the duty to provide information about UPS by the USP, this measure would have to extend to every postal service provider, both within the scope of the universal service and including all other services. Thus, it would ensure that the consumer can analyze and compare the conditions of all alternative services, including deliveries, prices, packaging, quality, claims, indemnification, schedules, access conditions, bonuses, and territorial scope of application. 


\section{The termination of a long-term relationship with the incumbent}

Some service providers have enjoyed their market power for many decades, operating as monopolies or with a high market share. The EU postal sector possessed monopolistic characteristics when the liberalization process began 15 years ago and even today most providers still operate above the market power threshold. The conventional workings of the postal sector have ensured relationships of extraordinary longevity. Long links with a service provider result in a relationship that is more complex and produces larger commercial deals (Reinartz and Kumar 2003). Long-term relationships contribute to shared values, identification between the parts, mutual information and certainty regarding behavior (Palmatier et al 2006). In so far as the provider offers a quality service and satisfactorily remedies any failures, the length of service in the relationship reinforces brand loyalty. Empirical studies, such as Woistschläger et al (2011), reveal that satisfaction, economic switching barriers, social ties, and habits are the drivers of customer loyalty. Empirical support for inter-temporal dependencies in brand choices, also known as state dependence effects, has been obtained in various contexts (Seetharaman 2003; Abramson et al 2000; Seetharaman et al 1999). The role of the informational advantage is studied by Villas-Boas (2004; 2006). This advantage may work as a barrier to entry because consumers tend to be loyal to the pioneering brands. White and Yanamandram (2006) explore the mediating effects of dependence and commitment on the relationship between switching costs and behavioral loyalty.

Loyalty to brand is considered one of the factors behind consumer reluctance to abandon the USP (Jonsson and Selander 2006). Brand loyalty reduces the vulnerability of the dominant operator against competition and acts as an entry barrier. If entrants into the market offer greater quality services, loyalty delays customer decisions to separate from their present provider and, at the same time, the incumbent has time to introduce quality improvements oriented to maintain customer portfolios. Therefore, brand loyalty constitutes an essential element of entry barriers in the postal sector. Along the same lines, Stigler (1968), Dijl et al (2006), and McAfee et al (2004) maintained that economies of scale would constitute an entry barrier only if consumers were loyal to the incumbent. That is to say, only where economies of scale are accompanied by a strong inertia on the demand side one can speak of authentic entry barriers in the postal sector. Thus, scale economies alone do not constitute an entry barrier.

Discomfort experienced by customers of a new supplier when adapting to the change are an unquantifiable cost that requires the estimator's best judgment. While this is an important factor, it must not be overemphasized.

\section{Conclusions}

A part of provider switching costs are related to the access to some incumbent infrastructures such as the postcode system, address database, post office boxes, delivery boxes, information on change of address, re-direction service and return to sender service. This provision shall be without prejudice to the right of Member States to adopt measures to ensure access to the postal network under transparent, proportional and non-discriminatory conditions. Directive 2008/6 states that Member States shall ensure that transparent, non-discriminatory access conditions are available to these elements of postal infrastructure or services. Parties can best define among themselves the most appropriate way to ensure interoperability. The examples in the postal sector show that ex ante soft regulation, where the NRA intervenes only in the case of disputes, seems to be the emerging model. 
We propose solutions that can help to reduce the problems of access to the postal network elements studied in this paper. Such solutions contribute undoubtedly to strengthen competition in the European postal market.

First, the access to postcodes is not identified by the NRAs as a bottleneck issue that calls for regulatory intervention. However, we assume that to defend the interest of the customers and to strengthen long-term competition, a mandatory access to postcodes could be imposed in order to allow competitors to deliver properly.

Second, with respect to the access to PO boxes, we propose a downstream access to the distribution center of the incumbent operator, as shown in Figure 1. In this case, the entrant does not install PO boxes in their locale. The senders of postal items do not need to subscribe to PO Boxes in each operator, thereby reducing the switching cost.

Third, regarding the redirection of mail service and the change of address service, we propose an ideal redirection service, which consists in sharing the RSC by all operators, as it is shown in Figure 2. The addressee hires the redirection service with the RSC and pays a fee for the administrative costs. Given that the financial and time costs are lower for the user, the switching costs are reduced when a customer changes the supplier and thus competition is promoted.

Fourth, the solution proposed here for the return to sender service is in line with that adopted in Sweden. The cost of return to sender service of postal items that have to be returned to locations outside the territory of the first operator (see Figure 3), when this operator is working in a limited geographical area, will be shared by each of the postal operators in proportion to the volume of mail. This solution reduces the three common types of switching costs: procedural, financial and relational costs.

Fifth, regarding the access to letterboxes, it is difficult to reach an optimal solution because the access to this element depends on issues such as its owners, location and access to them from inside or outside the buildings. In this case, the optimal solution is to pass a law that forces the postal operators to share the information on access to letterboxes, provided that security rules are complied with.

The proposed solutions reduce the switching costs and enhance the long term competition in the postal sector. Regulation on upstream and downstream access to the postal network is not homogeneous across states and, moreover its development has not reached a sufficient level so far.

Competition in the postal sector has experienced a limited progress compared to the initial proposals. The incumbents still retain a high market share. The causes of limited competition in the postal market lie in the insufficient and overly slow access regulations, the evolution of communication technologies to the detriment of classical postal communications, the economic crisis, as well as switching costs to a lesser extent.

\section{References}

Abramson, Charles, Rick L. Andrews, Imram S. Currim and Morgan Jones (2000) 'Parameter bias from unobserved effects in the multinomial logit model of consumer choice', Journal of Marketing Research 37(4): 410-26.

Armstrong, Mark S. and David E. Sappington (2006) 'Regulation, Competition and Liberalization', Journal of Economic Literature 44(2): 326-66.

Burnham, Thomas A., Judy K. Frels and Vijay Mahajan (2003) 'Consumer switching costs: A typology, antecedents, and consequences', Journal of the Academy of Marketing Science 31(2): 109-26. 
Crew, Michael A. and Paul R. Kleindorfer (2005) 'Competition, universal service and the graveyard spiral', in Michael A. Crew and Paul R. Kleindorfer (eds) Regulatory and economic challenges in the postal and delivery sector. New York, NY: Kluwer, pp. 1-30.

Crew, Michael A. and Paul R. Kleindorfer (2006) 'The welfare effects of entry and strategies for maintaining the USO in the postal sector', in Michael A. Crew and Paul R. Kleindorfer (eds) Progress Toward Liberalization of the Postal and Delivery Sector. New York, NY: Springer, pp. 3-22.

Dijl, Paul, Eric Van Damme and Pierre Larouche (2006). 'Regulating access to stimulate competition in postal markets?', in Michael A. Crew and Paul R. Kleindorfer (eds) Progress Toward Liberalization of the Postal and Delivery Sector. New York, NY: Springer, pp. 153-62.

Deligonul, Seyda, Daekwan Kim, Anthony S. Roath and Erin Cavusgil (2006) 'The Achilles' heel of an enduring relationship: Appropriation of rents between a manufacturer and its foreign distributor', Journal of Business Research 59(7): 802810.

Directive $97 / 67 / E C$ on common rules for the development of the internal market of Community postal services and the improvement of quality of service. Official Journal of the European Communities 21.1.98. L15/14-25.

Directive 2002/39/EC Amending Directive 97/67/EC with regard to the further opening to competition of Community postal services. Official Journal of the European Communities 5.7.2002. L176/21-25.

Directive 2008/6/EC Amending D/EC with regard to the full accomplishment of the internal market of Community postal services. Official Journal of the European Union 27.2.2008. L52/3-20.

ECORYS Nederland BV (2008) 'Main developments in the postal sector (20062008) ', report for the EC, September.

Fabra, Natalia and Alfredo García (2015) 'Dynamic price competition with switching costs', Dynamic Games and Applications 5(4): 540-567.

Fève, Fréderique, Jean-Pierre Florens, Frank Rodriguez and Soterios Soteri (2010) 'Forecasting mail volumes in an envolving markete invironment', in Michael A. Crew and Paul R. Kleindorfer (eds) Heightening Competition in the Postal and Delivery Sector. Northampton, MA: Edward Elgar Publishing Limited, pp. 116-134.

Fratini, Alessandra, Bernard Roy and Joost Vantomme (2010) 'Access to infrastructure and service elements in the postal sector', in Michael A. Crew and Paul R. Kleindorfer (eds) Heightening Competition in the Postal and Delivery Sector. Northampton, MA: Edward Elgar Publishing Limited, pp. 22-37.

Ghosh, Bikram and Michael R. Galbreth (2013) 'The Impact of Consumer Attentiveness and Search Costs on Firm Quality Disclosure. A Competitive Analysis', Management Science 59(11): 2604-2621.

Jones, Michael A., David L. Mothersbaugh and Sharon E. Beatty (2002) 'Why customers stay: measuring the underlying dimensions of services switching costs and managing their differential strategic outcomes', Journal of Business Research 55(6): 441-450.

Jones, Michael A., Kristy E. Reynolds, David L. Mothersbaugh and Sharon E. Beatty (2007) 'The positive and negative effects of switching costs on relational outcomes', Journal of Service Research 9(4): 335-355.

Jonsson, Per, and Sten Selander (2006) 'The Real Graveyard Spiral. Experiences from the Liberalized Swedish Postal Market', in Michael A. Crew and Paul R. Kleindorfer (eds) Progress Toward Liberalization of the Postal and Delivery Sector. New York, NY: Springer, pp. 359-366. 
Klemperer, Paul (1995) 'Competition when consumers have switching cost: An overview with applications to industrial organization, macroeconomics, and international trade', Review of Economic Studies 62(4): 515-539.

Levesque Terrence J., and Gordon H. McDougall (1996) 'Customer dissatisfaction: the relationship between types of problems and customer response', Canadian Journal of Administrative Sciences 13(3): 264-76.

Martin Vance L., Chris Paterson and Jessie X. Wang (2012) 'Forecasting letter volumes: augmenting econometric baseline projections', in Michael A. Crew and Paul R. Kleindorfer (eds), Multi-modal competition and the future of mail, Edward Elgar Publishing Limited, Northampton, Massachusetts, pp. 60-76.

McAfee Preston, Hugo Mialon and Williams, Michael A. (2004) 'What is a barrier to entry?. American Economic Review 94(4):461-65.

Okholm H., Winiarczyk M., Möller A. and Nielsen C. (2010) Main developments in the postal sector (2008-2010), Copenhagen Economics. www.copenhageneconomics.com

Palmatier Robert W., Rajiv P. Dant, Dhruv Grewal and Kenneth R. Evans (2006) 'Factors influencing the effectiveness of relationship marketing: A meta-analysis', Journal of Marketing 70(4):136-53.

Pateiro Rodríguez Carlos and Javier Prado Domínguez (2010) 'Un análisis de la transformación del servicio universal y el ámbito reservado en las políticas para la competencia del sector postal en la Unión Europea', Gestión y Política Pública 19, 187-237.

Pateiro Rodríguez Carlos, García Iglesias Jesús M. and José M. Barreiro Viñán (2013a) 'Las dimensiones territoriales urbana e interurbana de la liberalización del sector postal y cuestiones de ineficiencia del acceso a la red', Urban Public Economics Review 17, 78-105.

Pateiro Rodríguez Carlos, José M. Barreiro Viñán and García Iglesias Jesús M. (2013b) 'Efectos de los costes de cambio y de retención sobre el bienestar social en el proceso de apertura del servicio postal europeo', Anales de Economía Aplicada 27, 209-230.

Prado Domínguez, Javier and Carlos Pateiro Rodríguez (2012) 'La prestación del servicio postal universal ¿conlleva un riesgo inexorable de quiebra?', Revista de Ciencias Sociales 83 (1):1-9.

Patterson Paul G. and Tasman Smith (2003) 'A cross-cultural study of witching barriers and propensity to stay with service providers', Journal of Retailing 79(2): 107-20.

Plaut Economics (2007) 'Opening postal markets in Switzerland. Monopolistic bottlenecks, technical co-ordination and social regulations', Olten, January.

Porter, Michael E. (1980) Competitive strategy: Techniques for analysing industries and competitors, Free Press, New York.

Reinartz, Werner J. and Vinod Kumar (2003) 'The impact of customer characteristics on profitable lifetime duration', Journal of Marketing 67(1):77-99.

Seetharaman, P.B. (2003) 'Probabilistic versus random-utility models of state dependence: an empirical comparison', Journal of Research in Marketing 20(1): 87-96.

Seetharaman, P.B., Andrew Ainslie and Pradeep K. Chintagunta (1999) 'Investigating Household State Dependence Effects across Categories', Journal of Marketing Research 36(4):488-500. 
Sharma, Neeru and Paul G. Patterson (2000) 'Switching costs, alternative attractiveness and experience as moderators of relationship commitment in professional, consumer services', International Journal of Service Industry Management 11(5):470-90.

Shi, Mengze, Jeonweng Chiang and Byong-Duk Rhee (2006) 'Price Competition with Reduced Consumer Switching Costs: the Case of Wireless Number Portability in the Cellular Phone Industry', Management Science 52(1), 27-38.

Stigler, George J. (1968) 'Barriers to entry, economies of scale, and firm size', in George J. Stigler (ed.) The organization of Industry , Homewood, IL: Irwin, pp. 6770.

Trinkner, Urs and Martin Grossman (2006) 'Forecasting Swiss mail demand', Michael A. Crew and Paul R. Kleindorfer (eds), Progress toward Liberalization of the Postal and Delivery Sector. Springer, New York, pp. 267-80.

Valenzuela, Fredy, David Pearson and Roger Epworth (2005) 'Influence of switching barriers on service recovery evaluation', Journal of Service Research, Special Issue, December: 239-57.

Varela, Concepción, Rodolfo Vázquez and Victor Iglesias (2009) 'Comportamiento de abandono de la relación de un cliente con la empresa en un contexto de fallo y recuperación del servicio', Cuadernos de Economía y Dirección de la Empresa 12(40):143-70.

Viard, V. Brian (2007) 'Do switching costs make markets more or less competitive? The case of 800-number portability', RAND Journal of Economics 38(1): 146-63.

Villas-Boas, J. Miguel (2004) 'Consumer Learning, Brand Loyalty, and Competition', Marketing Science 23(1): 134-45.

Villas-Boas, J. Miguel (2006) 'Dynamic Competition with Experience Goods', Journal of Economics and Management Strategy 15(1):34-66.

White, Lesley and Venkata K. Yanamandram (2006) 'Exploring the switching costsbehavioural loyalty relationship amongst dissatisfied customers in the B2B services sector', Research online, University of Wollongong. Library. Available at: http://ro.uow.edu.au/commpapers/235/

White, Lesley and Venkata K. Yanamandram (2007) 'A model of customer retention of dissatisfied business services customers', Managing Service Quality 17(3):298-316.

Woisetschläger, David M., Patrick Lentz and Heiner Evaschitzky (2011) 'How habits, social ties, and economic switching barriers affect customer loyalty in contractual service setting', Journal of Business Research 64(8): 800-8. 